\title{
Prospective study of the fishery of the shrimp Plesionika narval (Fabricius, 1787) in the Northeastern Atlantic
}

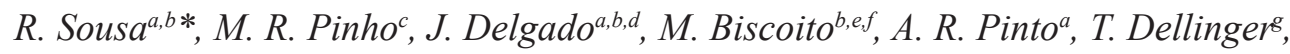 \\ L. Gouveia ${ }^{a}$, D. Carvalho and P. Henriques ${ }^{h}$

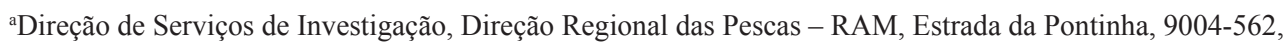 \\ Funchal, Portugal \\ bobservatório Oceânico da Madeira, Edifício Madeira Tecnopolo, Piso 0, 9020-105, Funchal, Portugal

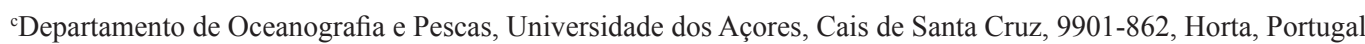 \\ ${ }^{d}$ Centro Interdisciplinar de Investigação Marinha e Ambiental - CIIMAR/CIMAR, Rua dos Bragas 289, \\ 450-123, Porto, Portugal \\ ${ }^{e}$ Museu de História Natural do Funchal, Rua da Mouraria, 31, 9000-047, Funchal, Madeira, Portugal \\ fEstação de Biologia Marinha do Funchal, Centro de Ciências do Mar e do Ambiente, Cais do Carvão, 9000-107, \\ Funchal, Madeira, Portugal \\ gLaboratório Biologia Marinha e Oceanografia, Universidade da Madeira, Estação Biologia Marinha do Funchal, \\ Cais do Carvão, Prom. Orla Marítima, 9000-107, Funchal, Portugal

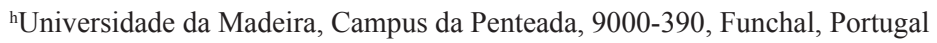 \\ *e-mail: ricardojorgesousa@gmail.com
}

Received: December 15, 2015 - Accepted: April 5, 2016 - Distributed: August 31, 2017

(With 2 figures)

\begin{abstract}
Several experimental surveys were carried out in the Northeastern Atlantic, Madeira archipelago from 1991 to 2008 to explore new fisheries resources. This study examined the selectivity of bottom and floating traps and the analysis of yield-per-recruit (YPR) and biomass-per-recruit (BPR) providing helpful insight to the management of the shrimp Plesionika narval. A total of 28,262 specimens were sampled and the analysis of length at first capture returned higher values when using floating traps indicating that these traps are more selective, exerting less pressure on the resource. The YPR and BPR analysis showed that the stock is under exploited for the studied area and suggests that the use of floating traps in the commercial fisheries of $P$. narval is recommended, which will allow a higher maximum allowable limit of exploitation and greater yield. The results suggest that $P$. narval has the potential to support a viable and sustainable fishery using floating traps.
\end{abstract}

Keywords: Plesionika narval, selectivity, sustainable yield, bottom traps, floating traps.

\section{Estudo prospectivo da pesca do camarão Plesionika narval (Fabricius, 1787) no Atlântico Nordeste}

\section{Resumo}

Vários cruzeiros de investigação foram realizados no Atlântico Nordeste, arquipélago da Madeira entre 1991 e 2008 visando a exploração de novos recursos pesqueiros. O presente estudo contemplou a comparação da seletividade de pesca entre armadilhas de fundo e flutuantes e a análise de rendimento por recruta (YPR) e biomassa por recruta (BPR) facultando informação essencial para a gestão do camarão Plesionika narval. Um total de 28,262 especimens foram amostrados e a análise de comprimento de primeira captura retornou valores mais elevados aquando da utilização de armadilhas flutuantes, indicando que essas armadilhas são mais seletivas e exercem menos pressão sobre o recurso. A análise YPR e BPR mostrou que o estoque se encontra sob explorado para a área de estudo e recomenda a utilização de armadilhas flutuantes na pesca comercial de $P$. narval, que permitirão um limite máximo de exploração com rendimento superior. Os resultados sugerem que $P$. narval tem o potencial para suportar uma pescaria viável e sustentável mediante a utilização de armadilhas flutuantes.

Palavras-chave: Plesionika narval, seletividade, rendimento sustentável, armadilhas de fundo, armadilhas flutuante. 


\section{Introduction}

Plesionika narval (Fabricius, 1787) is a cosmopolitan species occurring from the surface down to $910 \mathrm{~m}$ of depth in a large variety of habitats including muddy, sand-muddy, rocky bottoms and submarine caves (Biscoito, 1993; Holthuis, 1987). This species is acknowledged by FAO as a species of interest to fisheries (Holthuis, 1980), since it occurs in great abundance and is easily captured in bottom trawls and traps (Biscoito, 1993; Holthuis, 1987). P. narval is exploited in a small scale artisanal fishery in Madeira (Biscoito, 1993), the Canary Islands (González et al., 1997) and the Mediterranean Sea (Arculeo et al., 2002).

Several studies on the occurrence, biology, population structure and fisheries of $P$. narval were carried out in the Mediterranean Sea (Arculeo and Brutto, 2011; Arculeo et al., 2002; Thessalou-Legaki et al., 1989) Azores (Martins and Hargreaves, 1991), Madeira (Biscoito, 1993; Sousa et al., 2014) and the Canary Islands (González et al., 1997; Lozano et al., 1990). However no study has focused on the selectivity of the fishing traps and yield-and biomass-perrecruit analysis for this species, these studies are required for the implementation of administrative measures to preserve the stock and for monitoring the effectiveness of these measures (Leite Junior and Petrere Junior, 2006; Penha and Mateus, 2007).

Knowledge of the selectivity of commercial fishing gear is vital to the proper management of a commercial fishery. It is well-established that the selectivity and efficiency of crustacean traps are influenced by innumerous factors, such as: spatial and temporal deployments (Grubert and Lee, 2013) general design and/or shape (Butcher et al., 2012) number and/or type of entrances (Vazquez Archdale et al., 2006); bait type (Vazquez Archdale et al., 2008), size (Vazquez Archdale et al., 2006) and shape of meshes (Guillory and Hein, 1998).

Information on size-selectivity provides a useful assessment technique, because it allows the size distribution of the population to be inferred from the size distribution of the commercial catch (Millar, 1992). When information on catch and effort of the target fishery is available, then production models can be used to determine the strategy for optimizing the yield from the fishery (Gulland, 1983). When the species life history (growth, maturation and natural mortality) and minimal fishery information (selectivity) is available the yield per recruit analysis can be used. Yield per recruit models examine the trade-off between the gear selectivity and fishing effort in order to define an appropriate (sustainable) fishing pattern for the target fishery (Cadima, 2003). The aim of this work is to determine the potential effects of the fishery on exploited stocks of $P$. narval according to the fishing gear used through the yield-per-recruit and biomass-per-recruit models by the analysis of the status of the stock of P. narval in the archipelago of Madeira (Northeastern Atlantic). The information produced in this work will provide scientific knowledge that will assist in the sustainable management of the fisheries of this species.

\section{Material and Methods}

The specimens of $P$. narval examined in this study were obtained from 154 fishing sets carried out on the insular shelves and slopes off Madeira, Northeastern Atlantic $\left(32^{\circ} 00^{\prime}-33^{\circ} 30^{\prime} \mathrm{N} ; 15^{\circ} 30^{\prime}-18^{\circ} 00^{\prime} \mathrm{W}\right)$ in research surveys carried out from 1991 to 2008.

\subsection{Fishing gear}

Two types of traps were used in the research surveys, bottom traps set on the sea floor and floating traps operating on the water column at about $2 \mathrm{~m}$ above the sea floor using chicken meat as bait.

\subsubsection{Bottom trap}

The fishing gear was made up with 13 traps connected through a ground line ( $\varnothing 10 \mathrm{~mm}$ polypropylene rope) by $2 \mathrm{~m}$ length branch lines (Ø $6 \mathrm{~mm}$ nylon rope) and regularly spaced at $20 \mathrm{~m}$ from each other. At each end of the ground line, $10 \mathrm{~kg}$ weights were placed to anchor the line to the bottom. Two buoy-lines (Ø $12 \mathrm{~mm}$ polypropylene rope) with a variable length $(1.5 \times$ the depth $)$ were tied to the ends of the ground line. A $5 \mathrm{~kg}$ weight was placed at the end of the buoy-line to prevent surplus line floating near the surface. Buoys, equipped with reflectors and flags facilitated sighting at sea (Figure 1A).

The trap supporting structure was built in steel wire (Ø $0.80 \mathrm{~mm}$ ) lined with plastic net (Ø $15 \mathrm{~mm}$ side) and coupled to the frame with nylon rope $(\varnothing 1 \mathrm{~mm})$. The coffin shaped bottom trap with rectangular base of $80 \times 60 \mathrm{~cm}$ side and $50 \mathrm{~cm}$ height weighted $6 \mathrm{~kg}$. The bottom and three sides of the trap were lined internally with a plastic mesh of $5 \mathrm{~mm}$ up to a height of $23 \mathrm{~cm}$ to prevent the loss of shrimps during hauling. The fishing trap was fitted with two compartments for bait made with the same type of mesh used for lining the exterior of the trap, presenting a cylindrical shape of $22 \mathrm{~cm}$ in length $(\varnothing 10 \mathrm{~cm})$ and being placed on each side of the opening trap. A funnel-shaped opening allowing the entrance of animals through each cylinder base (Ø $23 \mathrm{~cm} \varnothing 19 \mathrm{~cm}$ outer and inner) was located on top of the trap. This trap model was developed and manufactured by the staff of the Funchal Natural History Museum (Biscoito et al., 1992).

\subsubsection{Floating trap}

The fishing gear comprised a ground line (Ø $20 \mathrm{~mm}$ polypropylene leaded rope), on which 75 floating traps were attached in regular intervals of $12 \mathrm{~m}$ using branch lines with $2 \mathrm{~m}$ length (Ø $7 \mathrm{~mm}$ polypropylene rope) (Figure 1B). In order to anchor the line to the bottom $65 \mathrm{~kg}$ weights were chained at each end of the ground line. Two buoy-lines ( $\varnothing 18 \mathrm{~mm}$ polypropylene rope) with variable length $(1.5 \times$ the depth) were also fixed to the ends of the ground line with shackles attached to fishing swivels. In order to prevent surplus line floating near the surface a $3 \mathrm{~kg}$ weight was placed at half of the length of the buoy-line. Large buoys, equipped with reflectors ( $3 \mathrm{~m}$ height), flags and acoustic emission devices were used to facilitate sighting and recovering. 

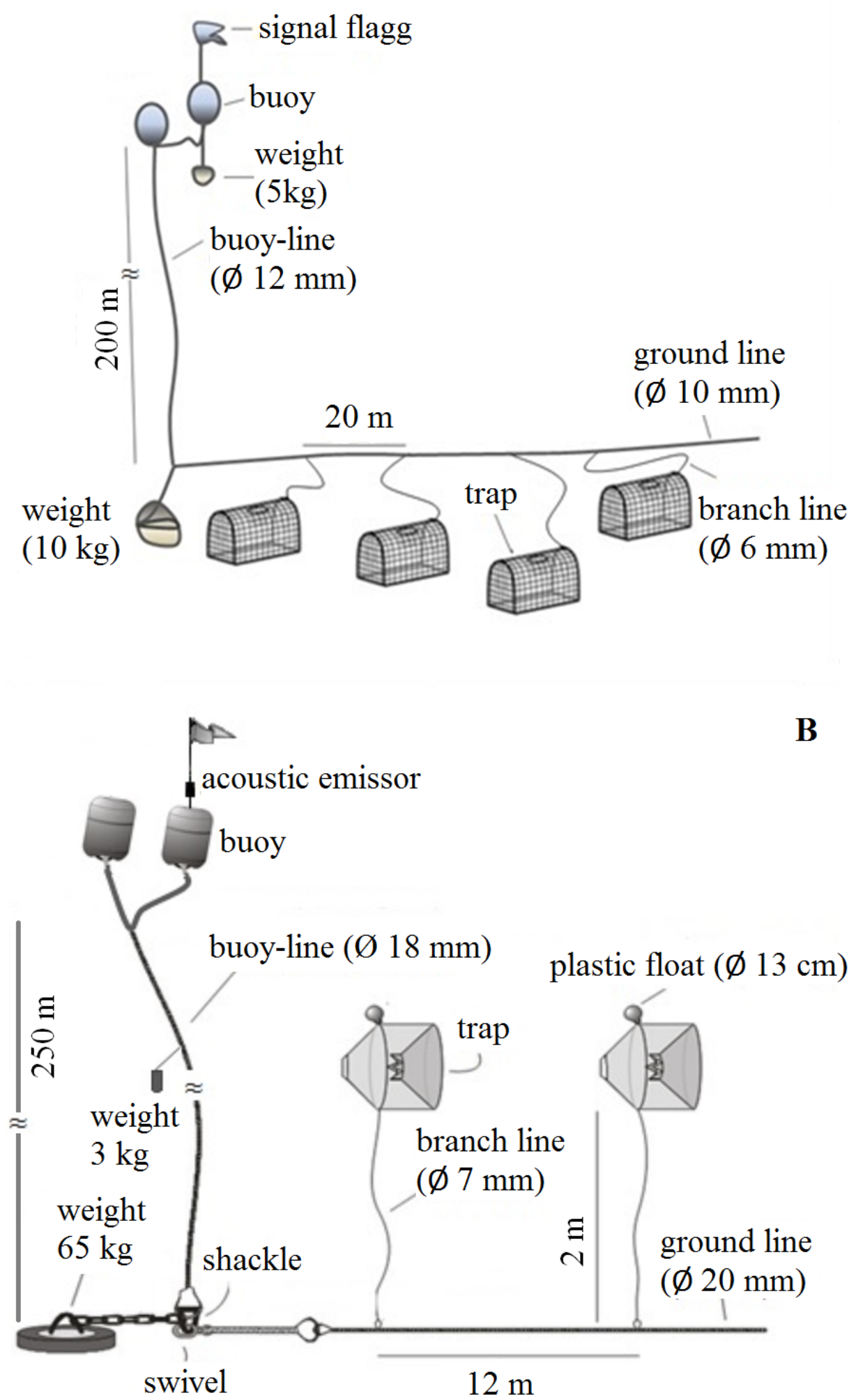

Figure 1. Schematic representation of a section of the fishing gear. (A) bottom traps (adapted from Biscoito et al., 1992); (B) floating traps (adapted from González et al., 1992). 
The structure supporting the trap was built in galvanized iron (Ø $3 \mathrm{~mm})$ and consisted of four rings supported by four stringers, lined with plastic net ( $15 \mathrm{~mm}$ side), coupled to the frame with nylon rope $(\varnothing 1 \mathrm{~mm})$. The frustoconical floating trap weighted $1.5 \mathrm{~kg}$ and was attached to a plastic float $(\varnothing 13 \mathrm{~cm})$ in its upper ring.

Prior to deployment echo-sounding surveys were always performed in order to avoid areas where the bottom was too steep and irregular avoiding the loss of fishing gear. Hauling was done following a standardized immersion time of ca. $24 \mathrm{~h}$.

\subsection{Data collection}

Relevant data was registered for all fishing sets such as date, geographic position, number of traps used, deployment and hauling time. Depths were recorded by an echosounder at the beginning and at the end of the fishing operations for each trap line.

All individual shrimps were then sampled. Their carapace length (CL) was measured to the nearest $0.01 \mathrm{~mm}$ from the posterior margin of the orbit to the posterior dorsal margin of the carapace using electronic digital calipers. The weight (W) was recorded using an electronic digital scale, with an accuracy of $0.01 \mathrm{~g}$. Sex was determined by the presence or absence of masculine appendages in the second pair of pleopods, through observation under a stereoscopic microscope (Zariquiey-Alvarez, 1968).

The existence of statistically significant differences between the mean CL for combined sexes, males and females according to type of fishing gear were tested through analysis of variance (ANOVA) with a 0.05 significance level (Sokal and Rohlf, 1995).

\subsection{Selectivity of fishing trap}

The comparison between the selectivity of floating and bottom traps was carried out through the analysis of the length-frequency data for combined sexes, females and males.

The probability of capture was calculated as a function of CL, in order to determine the average length of the first capture $\left(\mathrm{CL}_{50 \%}\right)$ where individuals have a $50 \%$ probability of being retained in the fishing gear (King, 1995). The data was fitted to the logistic curve model using the Equation 1 (King, 1995):

$$
P=\frac{1}{(1+\exp [-(a+b * \mathrm{CL})])}
$$

where $\mathrm{P}$ is the fraction of individuals retained by length, a and $b$ are constants and CL the lower limit of the carapace length class.

The parameters a and $b$ were obtained by linear regression, transforming the Equation 2 (King, 1995):

$\ln \left[\frac{P}{(1-P)}\right]=a+\mathrm{b}^{*} \mathrm{CL}$

The length of first capture was then estimated as $\mathrm{CL}_{50 \%}=-\mathrm{a} / \mathrm{b}$

\subsection{Relative yield-and biomass-per-recruit}

The biological parameters used in the yield- and biomass-per-recruit were estimated from the data collected in these research surveys and published in Sousa et al. (2014) and are shown in Table 1.

The current exploitation rate (E) was estimated according to Gulland (1971) as the fraction of mortality caused by fishing (Equation 3)

$\mathrm{E}=\mathrm{F} / \mathrm{Z}$

Relative yield-per-recruit(Y/R), the maximum sustainable exploitation rate (Emax) and exploitation rate at which the marginal increase of $\mathrm{Y} / \mathrm{R}$ is one tenth of its virgin stock (E0.1) were obtained according to the Beverton and Holt (1966) length-based method modified by Pauly and Soriano (1986) using the knife-edge selection (Equation 4):

$\mathrm{Y} / \mathrm{R}=\mathrm{EU}^{\mathrm{M} / \mathrm{K}}\left\{1-\frac{3 \mathrm{U}}{(1+\mathrm{m})}+\frac{3 \mathrm{U}^{2}}{(1+2 \mathrm{~m})}-\frac{\mathrm{U}^{3}}{(1+3 \mathrm{~m})}\right\}$

where $\mathrm{E}$ is the current exploitation rate, $\mathrm{U}=1-\left(\mathrm{CL}_{50 \%} / \mathrm{CL}_{\infty}\right)$ is the fraction of growth to be completed by the shrimp after entry into the exploitation phase, $\mathrm{M}$ is the natural mortality, $K$ is the growth coefficient and $m=(1-E) /(M / K)$.

The effect of mesh size was simulated by varying the parameter length-at-capture $\left(\mathrm{CL}_{50 \%}\right)$ in order to estimate the biological reference parameters F0.1 (fishing mortality at $10 \%$ of the slope of the yield per recruit curve), F0.5 (fishing mortality at $50 \%$ of the recruited biomass) and Fmax (maximum fishing mortality).

The relative biomass-per-recruit $(B / R)$ and the exploitation rate at which the stock has been reduced to $50 \%$ of its unexploited biomass (E0.5) were estimated from the Equation 5 (Pauly and Soriano, 1986):

$$
\mathrm{B} / \mathrm{R}=\frac{\mathrm{Y} / \mathrm{R}}{\mathrm{F}}
$$

where $\mathrm{Y} / \mathrm{R}$ is the relative yield-per-recruit and $\mathrm{F}$ the fishing mortality.

Relative yield-per-recruit (Y/R) and relative biomassper-recruit $(\mathrm{B} / \mathrm{R})$ were estimated using the software FISAT

Table 1. Biological parameters estimated for Plesionika narval caught in archipelago of Madeira, Northeastern Atlantic, according to sex (Sousa et al., 2014).

\begin{tabular}{lccc}
\multicolumn{1}{c}{\begin{tabular}{c}
\multicolumn{1}{c}{ Biological } \\
parameters
\end{tabular}} & $\begin{array}{c}\text { Combined } \\
\text { sexes }\end{array}$ & Females & Males \\
\hline $\begin{array}{l}\text { Asymptotic length } \\
\left(\mathrm{L}_{\infty}\right)\end{array}$ & 30.51 & 30.21 & 28.61 \\
$\begin{array}{l}\text { Growth coefficient } \\
(\mathrm{K})\end{array}$ & 0.440 & 0.450 & 0.430 \\
$\begin{array}{l}\text { Natural mortality } \\
(\mathrm{M})\end{array}$ & 0.77 & 0.78 & 0.77 \\
$\begin{array}{l}\text { Fishing mortality (F) } \\
\text { Total mortality (Z) }\end{array}$ & 1.06 & 1.35 & 0.93 \\
\hline
\end{tabular}


(Fish Stock Assessment Tools - FAO- ICLARM), VER 1.2.0 (Gayanilo et al., 2005).

\section{Results}

A total of 28,262 shrimps were sampled including 19,682 females and 8,580 males. The minimum and maximum CL of the specimens caught using floating traps were 2.45 and $28.61 \mathrm{~mm}(\overline{\mathrm{CL}}=16.57 \pm 2.71)$ and 7.00 and $22.00 \mathrm{~mm}(\overline{\mathrm{CL}}=12.88 \pm 2.66)$ for bottom traps. The ANOVA showed the existence of statistically significant differences in $\overline{\mathrm{CL}}$ between fishing traps $(\mathrm{F}=8,133.13, \mathrm{p}<0.05)$.

Females caught in floating traps showed CL minimum and maximum of 6.72 and $28.61 \mathrm{~mm}(\overline{\mathrm{CL}}=18.24 \pm 1.99)$ and of 7.00 and $22.00 \mathrm{~mm}(\overline{\mathrm{CL}}=13.54 \pm 2.55)$ using bottom traps. Males sampled in floating and bottom traps presented CL minimum and maximum of 2.45 and $27.22 \mathrm{~mm}(\overline{\mathrm{CL}}=15.35 \pm 2.51)$ and of 7.00 and $18.00 \mathrm{~mm}(\overline{\mathrm{CL}}=10.78 \pm 1.77)$, respectively.

ANOVA demonstrated that there were statistically significant differences in $\overline{\mathrm{CL}}$ for females $(\mathrm{F}=9,659.94$; $\mathrm{p}<0.05)$ and males $(\mathrm{F}=6,937.38 ; \mathrm{p}<0.05)$ between the fishing traps.

\subsection{Selectivity of fishing trap}

The CL at first capture for $P$. narval was estimated at $14.20 \mathrm{~mm}$ when using floating traps and $12.25 \mathrm{~mm}$ when using bottom traps during the study period for combined sexes.

Regarding the length at first capture according to sex the analysis showed that females had larger $\mathrm{CL}_{50 \%}$ than males for both types of fishing traps. For females the $\mathrm{CL}_{50 \%}$ was $16.36 \mathrm{~mm}$ for floating traps and $12.72 \mathrm{~mm}$ for bottom

Table 2. $\mathrm{Y}^{\prime} / \mathrm{R}$ and $\mathrm{B} / \mathrm{R}$ optimum values of Plesionika narval for floating and bottom traps according to sex.

\begin{tabular}{llcccc}
\hline & & Emax & E0.1 & E0.5 & Ecurrent \\
\hline \multirow{4}{*}{$\begin{array}{llcl}\text { Floating } \\
\text { traps }\end{array}$} & Combined & 0.709 & 0.607 & 0.354 & 0.579 \\
& sexes & & & & \\
& Females & 0.814 & 0.707 & 0.376 & 0.634 \\
& Males & 0.700 & 0.606 & 0.351 & 0.547 \\
Bottom & Combined & 0.621 & 0.515 & 0.333 & 0.579 \\
traps & sexes & & & & \\
& Females & 0.643 & 0.555 & 0.339 & 0.634 \\
& Males & 0.602 & 0.509 & 0.327 & 0.547 \\
\hline
\end{tabular}

traps. $\mathrm{CL}_{50 \%}$ for males caught with floating and bottom traps were 13.17 and $10.72 \mathrm{~mm}$ respectively.

\subsection{Relative yield-and biomass-per-recruit}

The current exploitation rate of $P$. narval was estimated at 0.579 for combined sexes, 0.634 for females and 0.547 for males. An overview of the $\mathrm{Y} / \mathrm{R}$ and $\mathrm{B} / \mathrm{R}$ parameters (Emax, E0.1, E0.5 and Ecurrent) is given in Table 2.

The Emax that gives the maximum relative yield-perrecruit at maximum sustainable yield (MSY) for combined sexes was 0.709 for floating traps (Figure 2A) and 0.621 for bottom traps (Figure 2D). The E0.1 was higher for floating traps $(0.607)$ than for bottom traps $(0.515)$. The E0.5 was 0.354 for floating traps and 0.333 for bottom traps.

Females showed an Emax of 0.814 and 0.643 for floating (Figure 2B) and bottom traps (Figure 2E) respectively. The values of E0.1 for females varied between 0.707 for floating traps and 0.555 for bottom traps. The level of exploitation E0.5 was 0.376 for floating and 0.339 for bottom traps.

In regard to males, Emax was estimated to be 0.700 and 0.602 for floating traps (Figure 2C) and bottom traps (Figure 2F) respectively. E0.1 was estimated at 0.606 and 0.509 for floating and bottom traps respectively. The level of exploitation E0.5 was 0.351 for floating traps and 0.327 for bottom traps.

The limit reference points obtained by simulating Y/R for different lengths at capture are presented in Table 3. Both floating and bottom traps evidenced a trend of decreasing Fmax, F0.1 and F0.5 with decreasing length-at capture.

The simulation of $Y / R$ varying length-at-capture for floating traps returned values of Fmax that ranged from 1.307 to 1.724 for females, in regards to males the values of Fmax varied between 1.122 and 1.477. When considering combined sexes the values ranged from 1.136 to 1.486 .

For bottom traps the values of Fmax varied between 1.049 and 1.338 for females. As for males the values of Fmax ranged between 0.966 and 1.244. The variation observed for Fmax for combined sexes ranged between 1.016 and 1.290 .

\section{Discussion}

The experimental design used in this study allowed quantifying the effects of two types of fishing gear in the artisanal fishery of $P$. narval in regards to selectivity and

Table 3. Limit reference points estimated according to length at first catch for floating and bottom traps.

\begin{tabular}{|c|c|c|c|c|c|c|c|c|c|c|c|c|}
\hline & \multicolumn{4}{|c|}{ Combined sexes } & \multicolumn{4}{|c|}{ Females } & \multicolumn{4}{|c|}{ Males } \\
\hline & $\mathrm{CL}_{50 \%}$ & F 0.5 & F 0.1 & Fmax & $\mathrm{CL}_{50 \%}$ & F 0.5 & F 0.1 & Fmax & $\mathrm{CL}_{50 \%}$ & F 0.5 & F 0.1 & Fmax \\
\hline \multirow{3}{*}{$\begin{array}{l}\text { Floating } \\
\text { traps }\end{array}$} & 12.73 & 0.609 & 0.942 & 1.136 & 14.36 & 0.651 & 1.125 & 1.307 & 11.17 & 0.604 & 0.952 & 1.122 \\
\hline & $14.73^{*}$ & 0.646 & 1.111 & 1.286 & $16.36^{*}$ & 0.690 & 1.292 & 1.495 & $13.17 *$ & 0.642 & 1.109 & 1.281 \\
\hline & 16.73 & 0.683 & 1.283 & 1.468 & 18.36 & 0.727 & 1.501 & 1.724 & 15.17 & 0.683 & 1.290 & 1.477 \\
\hline \multirow{3}{*}{$\begin{array}{l}\text { Bottom } \\
\text { traps }\end{array}$} & 10.26 & 0.575 & 0.860 & 1.016 & 10.72 & 0.584 & 0.838 & 1.049 & 8.71 & 0.556 & 0.734 & 0.966 \\
\hline & $12.26^{*}$ & 0.609 & 0.935 & 1.142 & $12.72 *$ & 0.620 & 1.017 & 1.180 & $10.71^{*}$ & 0.595 & 0.928 & 1.093 \\
\hline & 14.26 & 0.646 & 1.111 & 1.290 & 14.72 & 0.659 & 1.122 & 1.338 & 12.71 & 0.635 & 1.025 & 1.244 \\
\hline
\end{tabular}

* current value of $\mathrm{CL}_{50 \%}$. 
A

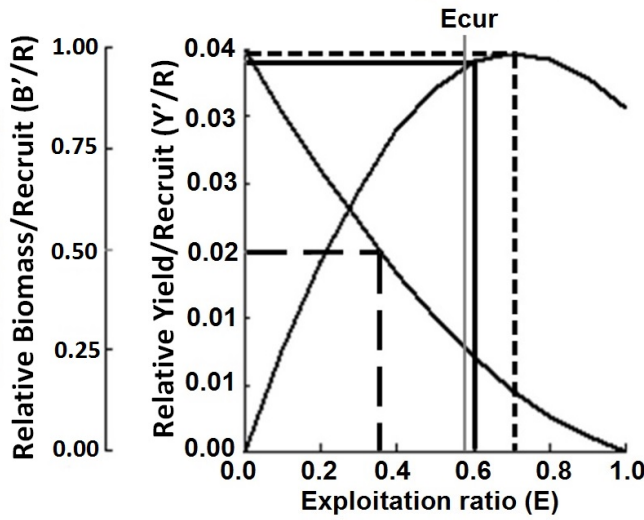

B

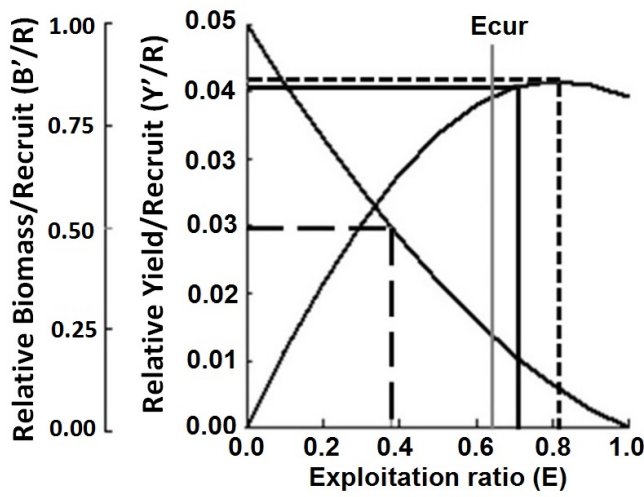

C
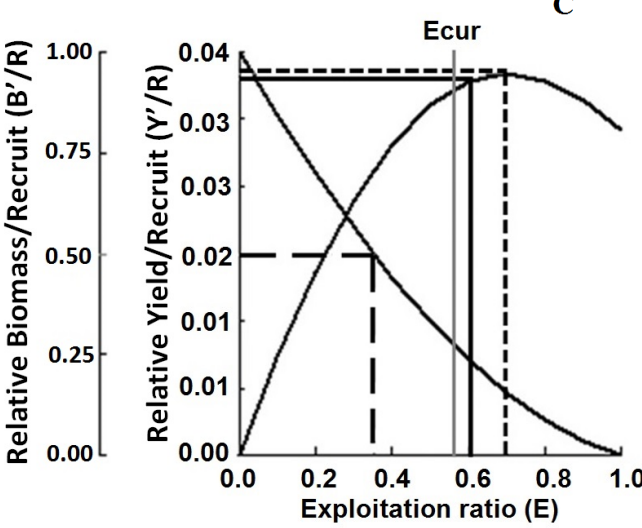

$E_{0.1}-E_{0.5}-$
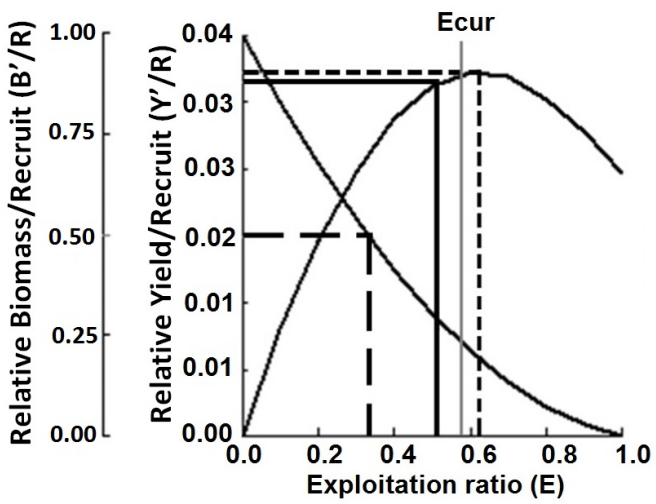

E
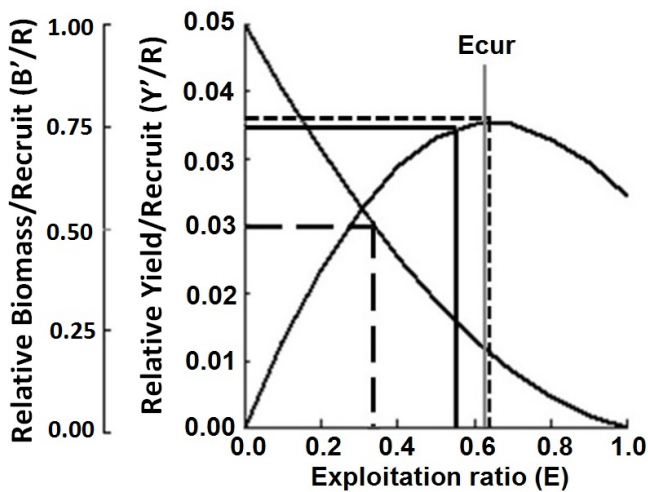

F
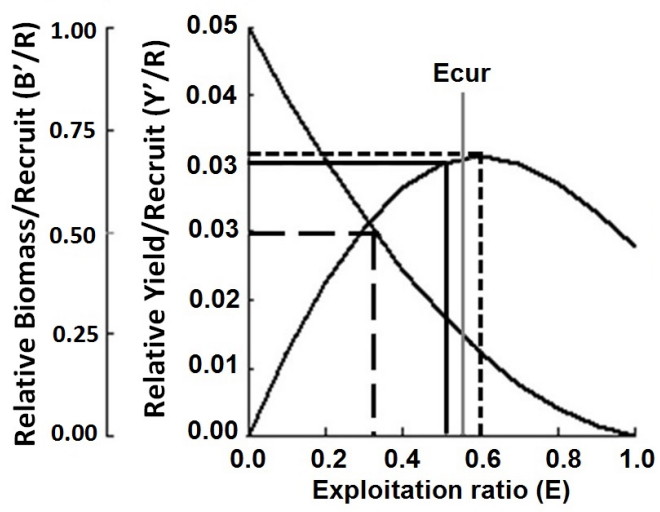

$E_{\max }----$

Figure 2. Relative yield-and biomass-per-recruit for Plesionika narval using floating traps (A) combined sexes; (B) females; (C) males and bottom traps (D) combined sexes; (E) females; (F) males.

yield analysis providing helpful insight to the management of the fisheries of this species.

\subsection{Selectivity of fishing gear}

Selectivity assessment of fishing gear and development of methods for selective capture are urgently required in order to provide a sustainable exploitation of fishing resources (Hall et al., 2000). Selectivity is also one of the most important data used for the adequate management of fisheries permitting to define sustainable levels of fishing mortality through the option of the adequate fraction of the population exploited by size (Sobrino et al., 2000).

The carapace length from which $50 \%$ of the shrimp caught in the study area become vulnerable to the fishing 
gear employed was higher when using floating traps for combined sexes, males and females.

The fact that the capture lengths are smaller for bottom traps and larger in floating, suggests that there is a segregation of sizes along the vertical distribution of this species, in which smaller specimens occur preferably closer to the bottom and larger specimens in the water column. Therefore smaller individuals may be more vulnerable to bottom traps and larger individuals to floating traps. However, the use of different mesh for both types of traps also determines the average size of the samples as has been observed for Pandalus borealis Krøyer, 1838 (He and Balzano, 2007), Penaeus japonicus Spence Bate, 1888 (Fujimori et al., 1996), Parapenaeus longirostris (Lucas, 1846) (Sobrino et al., 2000). As such, the mesh size of the traps and their positioning in relation to the ocean floor appear to be the main factors that influence the average length of capture.

Length at first catch was higher for females sampled with floating traps and smaller for males caught with bottom traps. The mean carapace length between sexes showed statistically significant differences by fishing trap, which was due primarily to the mean CL being higher in females than in males. These results are probably explained by possible vertical size segregation, with females more commonly found in the water column and males in the benthos. Since females were found to have a larger mean $\mathrm{CL}$, they are possibly more adapted to survive in the water column than males with a smaller mean CL, as a result of differential morphological development, reproductive investment and distinct habitat preference (King, 1995).

Higher values of length at first capture might also be explained by differences in mesh size used in the two types of fishing traps. The use of larger mesh size in this fishery would reduce the capture of smaller individuals, i.e. recruits and juveniles as showed by the simulation of yield per recruit according to length-at-capture where a decrease in mesh size promotes a decrease in the estimated limit references points of the $\mathrm{Y} / \mathrm{R}$ analysis, which is in consonance with what was reported in other studies for several shrimp species such as Parapenaeus longirostris (Sobrino et al., 2000), Metapenaeus macleayi (Haswell, 1879) and Penaeus plebejus Hess, 1865 (Broadhurst et al., 2004) that showed lower discards and larger individuals with increasing mesh size of fishing gear (Arellano-Torres et al., 2006; Burgos-Leon et al., 2009).

The increase in mesh size could cause an immediate drop of the captured amounts of shrimps (Lindner, 1966), however these short time losses would be compensated by medium term gains as a result of an increase in stock productivity (Neal and Maris, 1985), therefore leading to important economic benefits (Sobrino et al., 2000). The results are consistent with previous findings that suggest that the use of higher mesh size would avoid overexploitation risks for small shrimps as stated by Arellano-Torres et al. (2006). Therefore, the recommended mesh size for commercial fishery of $P$. narval should have at least $15 \mathrm{~mm}$ diameter in order to ensure a sustainable exploitation of this resource as it would prevent capture of immature individuals since size at first maturity was estimated at $14.61 \mathrm{~mm}$ (Sousa et al., 2014).

Floating traps are also less prone to capture bycatch and do limited damage to the deep-water ecosystems, unlike traditional bottom traps (Arrasate-López et al., 2012) as indicated by the studies on the effect of trapping in the deep-living shrimp communities by Gillett (2008) and Burgos-León et al. (2009) for stock size assessment and management purposes concluding that floating traps are the best fishing method for several shrimp species.

\subsection{Yield and biomass per recruitment}

One of the main reasons to study the growth of marine organisms and describe it in the form of the von Bertalanffy growth function is to do stock assessment using the yield-per-recruit and biomass per-recruit (B/R) models. These analyses are essential to obtain long term reference points and evaluate the exploitation status of the study species (Sparre et al., 1989).

The Y/R model is a principal steady state model that describes the state of stock and the yield considering the fishing pattern has been constant over a long period so that all individuals of the species are vulnerable to capture after recruitment (Sparre et al., 1989) and returns a value of maximum sustainable yield. This MSY value estimated for P. narval in the study area, was higher when using floating traps compared to when using bottom traps for combined sexes, females and males, indicating that the floating traps are more selective and allow a more sustainable exploitation. Between groups, females showed higher values of maximum yield in contrast to males. The most prominent differences between groups occurred when using floating traps, which showed higher selectivity concerning sexes than when using bottom traps.

The current exploitation rate (Ecur), based on fishing mortality was lower than the MSY in both fishing traps used, indicating that the stock of $P$. narval is below the maximum sustainable fishing pressure for all groups studied regardless the type of traps used. However, when considering the economical optimum rate (E0.1), the Ecur is below the accepted limits when using floating traps and above the limit when using bottom traps indicating that an increase in fishing effort using bottom traps will only marginally increase the yield and possibly exceed the MSY since fisheries tend to be most profitable at production levels below MSY (Morgan, 2001).

The use of the bottom traps returned values of exploitation closer to the MSY, demonstrating that if these traps are to be used in the fishery of $P$. narval they will exert higher fishing pressure on the stock and the species will be exploited around its limits of sustainability. Fishing at or near the maximum sustainable yield is not usually recommended because of inevitable uncertainties that affect the exact value of this quantity (Morgan, 2001). The values of Fmax, F0.1 and F0.5 obtained for bottom traps were consistently inferior to those regarding floating traps indicating that the latter allow higher levels of exploitation and greater yield. 
These results put in evidence the overall health of the stock of $P$. narval in the study area, which has the potential to support a viable and sustainable fishery using floating traps as reported for Plesionika edwardsii (Brandt, 1851) and Heterocarpus ensifer A. Milne-Edwards, 1881 in the Canary Island by Arrasate-López et al. (2012).

The relative biomass per recruit $(\mathrm{B} / \mathrm{R})$ model has a reference point called E0.5, which is defined as the value at which $\mathrm{B} / \mathrm{R}$ is reduced to half its non-exploited level (Gulland, 1983; Pauly and Munro, 1984). The value of E0.5 obtained for $P$. narval was higher when using floating traps, with females presenting themselves as the group with higher levels of exploitation, for both fishing traps employed. Regardless the type of trap used, the estimated Ecur is above E0.5 for all groups studied indicating that even though the stock is not being over-exploited, it might be at risk of suffering reduced reproductive capacity. Nonetheless, using bottom traps seems to have more impact on the recruited biomass, which might be related to the fact that smaller specimens of $P$. narval are more commonly caught in the benthos.

\section{Conclusions and Recommendations}

The results suggest that $P$. narval has the potential to support a viable and sustainable fishery and the implementation of floating traps in commercial fishing instead of bottom traps is recommended.

The use of floating traps will allow the increase of the mean size and age at first capture and consequently achieving a larger MSY. The use of this gear type may also allow more profitable and sustainable harvests avoiding overfishing and bycatch problems due to its selectivity properties.

The minimum size of mesh to be used in these traps should be $15 \mathrm{~mm}$, but in order to avoid overfishing larger mesh sizes are recommended.

The measures incorporating selectivity criteria such as type of trap and mesh size should be complemented by fishery closures during the main reproductive period in late Summer-Autumn (Sousa et al., 2014), which would contribute towards reducing the risks of overexploitation and promote a sustainable fishery. Also, due to the low abundance of this shrimp in the study area, fishing activity should be carried out on a small-scale basis.

\section{Acknowledgements}

The authors wish to thank the Fisheries Research Service (DSI) from the Regional Directorate of Fisheries of the Autonomous Region of Madeira and the Funchal Natural History Museum (MMF). We are also grateful to the technicians of DSIDP and MMF for their help in the course of this work. Financial support was granted by JNICT Portugal (now FCT) under contract PMCT/C/MAR/985/90, the UE FEDER in the framework of the PIC INTERREG III B projects PESCPROF 1, 2 and 3 (MAC/4.2/M12, 03/MAC/4.2/M8 and 05/MAC/4.2/M11), the Municipality of Funchal and the Regional Government of Madeira.

\section{References}

ARCULEO, M. and BRUTTO, S., 2011. Growth and reproduction data of Plesionika narval (Decapoda, Caridea, Pandalidae) off the island of Ustica (southern Tyrrhenian Sea). Crustaceana, vol. 84, no. 11, pp. 1367-1375. http://dx.doi.org/10.1163/156854011X596955.

ARCULEO, M., MAZZOLA, A. and RIGGIO, S., 2002. Catture sperimentali con le nasse di Plesionika narval (Fabr.) (Crustacea Decapoda) nell'isola di Ustica (Tirreno Meridionale). Naturalista Siciliano, $I V-X X V I$, vol. 2, no. 1, pp. 13-20.

ARELLANO-TORRES, A., PÉREZ-CASTAÑEDA, R. and DEFEO, O., 2006. Effects of a fishing gear on an artisanal multispecific penaeid fishery in a coastal lagoon of Mexico: mesh size, selectivity and management implications. Fisheries Management and Ecology, vol. 13, no. 5, pp. 309-317. http:// dx.doi.org/10.1111/j.1365-2400.2006.00507.x.

ARRASATE-LÓPEZ, M., TUSET, V.M., SANTANA, J.I., GARCÍA-MEDEROS, A., AYZA, O. and GONZÁLEZ, J.A., 2012. Fishing methods for sustainable shrimp fisheries in the Canary Islands (North-West Africa). African Journal of Marine Science, vol. 34, no. 3, pp. 331-339. http://dx.doi.org/10.2989/1 814232X.2012.725281.

BEVERTON, R.J.H. and HOLT, S.J., 1966. Manual of methods for fish stock assessment: Part II. Tables of yield function. Rome: FAO, pp. 1-111. FAO Fisheries Technical Papers, no. 8.

BISCOITO, M.J., 1993. An account of the shrimps of the family Pandalidae (Crustacea, Decapoda, Caridea) in Madeiran waters. Courier Forschungsinstitut Senckenberg, vol. 159, pp. 321-325.

BISCOITO, M.J., PINTO, A.R., MAUL, G.E., FARIA, G.T. and AMORIM, A.B., 1992. Estudo ecológico e biológico das comunidades de peixes e crustáceos decápodes bentónicos da vertente continental da Madeira. Lisboa: FCT. 59 p. Relatório de Progresso do Projecto PMCT/C/Mar/985/90.

BROADHURST, M.K., MILLAR, R.B., KENNELLY, S.J., MACBETH, W.G., YOUNG, D.J. and GRAY, C.A., 2004. Selectivity of conventional diamond- and novel square-mesh codends in an Australian estuarine penaeid-trawl fishery. Fisheries Research, vol. 67, no. 2, pp. 183-194. http://dx.doi.org/10.1016/j. fishres.2003.09.043

BURGOS-LEÓN, A., PÉREZ-CASTANÉDA, R. and DEFEO, O., 2009. Discards from the artisanal shrimp fishery in a tropical coastal lagoon of Mexico: spatio-temporal patterns and fishing gear effects. Fisheries Management and Ecology, vol. 16, no. 2, pp. 130-138. http://dx.doi.org/10.1111/j.1365-2400.2009.00653.x.

BUTCHER, P.A., LELAND, J.C., BROADHURST, M.K., PATERSON, B.D. and MAYER, D.G., 2012. Giant mud crab (Scylla serrata): relative efficiencies of common baited traps and impacts on discards. ICES Journal of Marine Science, vol. 69, no. 8, pp. 1511-1522. http://dx.doi.org/10.1093/icesjms/fss109.

CADIMA, E.L., 2003. Fish stock assessment manual. Rome: FAO, pp. 1-161. FAO Fisheries Technical Papers, no. 393.

FUJIMORI, Y., TOKAI, T., HIYAMA, S. and MATUDA, K., 1996. Selectivity and gear efficiency of trammel nets for kuruma prawn (Penaeus japonicus). Fisheries Research, vol. 26, no. 1-2, pp. 113-124. http://dx.doi.org/10.1016/0165-7836(95)00392-4.

GAYANILO, F.C.J.R., SPARRE, P. and PAULY, D., 2005. The FAOICLARM Stock Assessment Tools (FISAT II): user's Guide. Rome: FAO, pp. 1-168. FAO Computerized Information Series, vol. 8.

GILLETT, R., 2008. Global study of shrimp fisheries. Rome: FAO, pp. 1-331. FAO Fisheries Technical Papers, no. 475. 
GONZÁlEZ, J.A., CARRILLO, J., SANTANA, J.I., BAÑO, P.M. and VIZUETE, F., 1992. La pesquería de la Quisquilla, Plesionika edwardsii (Brandt, 1851), con tren de nasas en el Levante español. Ensayos a pequeña escala en Canarias. Informes Técnicos de Scientia Marina, vol. 170, pp. 1-31.

GONZÁLEZ, J.A., TUSET, V.M., LOZANO, I.J. and SANTANA, J.I., 1997. Biology of Plesionika narval (Crustacea, Decapoda, Pandalidae) around the Canary Islands (Eastern Central Atlantic). Estuarine, Coastal and Shelf Science, vol. 44, no. 3, pp. 339-350. http://dx.doi.org/10.1006/ecss.1996.0122.

GRUBERT, M.A. and LEE, H.S., 2013. Improving gear selectivity in Australian mud crab fisheries. Australia: Northern Territory Government. 99 p. Fishery Report, no. 112.

GUILLORY, V. and HEIN, S., 1998. An evaluation of square and hexagonal mesh blue crab traps with and without escape rings. Journal of Shellfish Research, vol. 17, pp. 561-562.

GULLAND, J.A., 1971. The fish resources of the ocean. London: Fishing News Books. 255 p.

GULLAND, J.A., 1983. Fish stock assessment: a manual of basic methods. Chichester: Wiley Interscience. $233 \mathrm{p}$.

HALL, M.A., ALVERSON, D.L. and METUZALS, K.L., 2000. By-catch: problems and solutions. Marine Pollution Bulletin, vol. 41, no. 1-6, pp. 204-219. http://dx.doi.org/10.1016/S0025$326 \times(00) 00111-9$.

HE, P. and BALZANO, V., 2007. Reducing the catch of small shrimps in the Gulf of Maine pink shrimp fishery with a sizesorting grid device. ICES Journal of Marine Science, vol. 64, no. 8, pp. 1551-1557. http://dx.doi.org/10.1093/icesjms/fsm098.

HOLTHUIS, L.B., 1980. FAO species catalogue. Shrimps and Prawns of the world: an annotated catalogue of species of interest to fisheries. FAO Fisheries Circular, vol. 125, no. 1, pp. 1-271.

HOLTHUIS, L.B., 1987. Crevettes. In: W. FISCHER, M. SCHNEIDER and M.L. BAUCHOT, eds. Fiches FAO d'identification des espèces pour les besoins de la pêche. Méditerranée et Mer Noire. Zone de pêche 37 (revision 1), 1, végétaux et invertébrés. Rome: FAO, pp. 189-292.

KING, M., 1995. Fisheries biology assessment and management. Oxford: Fishing News Books. 342 p.

LEITE JUNIOR, N.O. and PETRERE JUNIOR, M., 2006. Growth and mortalities of the Pink-shrimp Farfantepenaeus brasiliensis Latreille, 1970 and F. paulensis PÉREZ-FARFANTE1967 in Southeast Brazil. Brazilian Journal of Biology $=$ Revista Brasileira de Biologia, vol. 66, no. 2A, pp. 523-536. http://dx.doi.org/10.1590/ S1519-69842006000300019.

LINDNER, M.J., 1966. What we know about shrimp size and the Tortugas fishery. Proceedings of the Gulf and Caribbean Fisheries Institute, vol. 18, pp. 18-26.

LOZANO, G., CARRILLO, J., CALDENTEY, M., SANTANA, J., LOZANO, I., GONZÁLEZ, J., JIMENÉZ, S., LOZANO, F., BRITO, A., FANLO, M. and HERNÁNDEZ, C., 1990. Distribución estacional y batimétrica de Pandálidos en el talud de Gran Canaria. In: L. GALLEGO-CASTEJON, ed. Bentos VI. Palma de Maiorca: Bilbilis, pp. 213-221.

MARTINS, H. and HARGREAVES, P., 1991. Shrimps of the Families Pandalidae and Hippolytidae (Crustacea: Decapoda) caught in benthic traps off the Azores. Arquipélago Life and Marine Sciences, vol. 9, pp. 47-61.

MILLAR, R.B., 1992. Estimating the size-selectivity of fishing gear by conditioning on the total catch. Journal of the American
Statistical Association, vol. 87, no. 420, pp. 962-968. http://dx.doi. org/10.1080/01621459.1992.10476250.

MORGAN, G.R., 2001. Initial allocation of harvesting rights in the rock lobster fishery of Western Australia. In: R. SHOTTON, ed. Case studies on the allocation of transferable quota rights in fisheries. Rome: FAO, pp. 152-158.

NEAL, R.A. and MARIS, R.C., 1985. Fisheries biology of shrimps and shrimplike animals. In: A.J.J.R. PROVENZANO, ed. The Biology of Crustacea. London: Academic Press, pp. 1-110. Economic Aspects: Fisheries and Culture, vol. 10.

PAULY, D. and MUNRO, J.L., 1984. Once more on the comparison of growth in fish and invertebrates. ICLARM Fishbyte, vol. 2, no. 1 , pp. 21.

PAULY, D. and SORIANO, M.L., 1986. Some practical extensions to Beverton and Holt's relative yield-per-recruit model. In: J.L. MACLEAN, L.B. DIZON and L.V. HOSILLOS, eds. The first asian fisheries forum. Manila: Asian Fisheries Society, pp. 491-496.

PENHA, J.M.F. and MATEUS, L.A.F., 2007. Sustainable harvest of two large predatory catfish in the Cuiabá river basin, northern Pantanal, Brazil. Brazilian Journal of Biology $=$ Revista Brasileira de Biologia, vol. 67, no. 1, pp. 81-89. http://dx.doi.org/10.1590/ S1519-69842007000100011. PMid:17505753.

SOBRINO, I., GARCÍA, T. and BARO, J., 2000. Trawl gear selectivity and the effect of mesh size on the deep-water rose shrimp (Parapenaeus longirostris, Lucas, 1846) fishery off the gulf of Cádiz (SW Spain). Fisheries Research, vol. 44, no. 3, pp. 235-245. http://dx.doi.org/10.1016/S0165-7836(99)00090-9.

SOKAL, R.R. and ROHLF, F.J., 1995. Biometry: the principles and practice of statistics in biological research. New York: W.H. Freeman. 887 p.

SOUSA, R., HENRIQUES, P., BISCOITO, M., PINTO, A.R., DELGADO, J., DELLINGER, T., GOUVEIA, L. and PINHO, M.R., 2014. Considerations on the Biology of Plesionika narval (Fabricius, 1787) in the Northeastern Atlantic. Turkish Journal of Fisheries and Aquatic Sciences, vol. 14, pp. 727-737. http:// dx.doi.org/10.4194/1303-2712-v14_3_15.

SPARRE, P., URSIN, E. and VENEMA, S.C., 1989. Introduction to tropical fish stock assessment. part 1: manual. Rome: FAO, pp. 1-376. FAO Fisheries Technical Papers, no. 306.

THESSALOU-LEGAKI, M., FRANTZIS, A., NASSIOKAS, K. and HATZINIKOLAOU, S., 1989. Depth zonation in a Parapandalus narval (Crustacea, Decapoda, Pandalidae) population from Rhodos Island, Greece. Estuarine, Coastal and Shelf Science, vol. 29, no. 3, pp. 273-284. http://dx.doi.org/10.1016/0272-7714(89)90058-9.

VAZQUEZ ARCHDALE, M., AÑASCO, C.P. and TAHARA, Y., 2008. Catches of swimming crabs using fish mince in "teabags" compared to conventional fish baits in collapsible pots. Fisheries Research, vol. 91, no. 2-3, pp. 291-298. http://dx.doi.org/10.1016/j. fishres.2007.12.005

VAZQUEZ ARCHDALE, M., KARIYAZONO, L. and AÑASCO, C.P., 2006. The effect of two pot types on entrance rate and entrance behavior of the invasive Japanese swimming crab Charybdis japonica. Fisheries Research, vol. 77, no. 3, pp. 271-274. http:// dx.doi.org/10.1016/j.fishres.2005.11.012.

ZARIQUIEY-ALVAREZ, R., 1968. Crustáceos Decápodos Ibéricos. Investigaciones Pesqueras, vol. 32, pp. 1-510. 